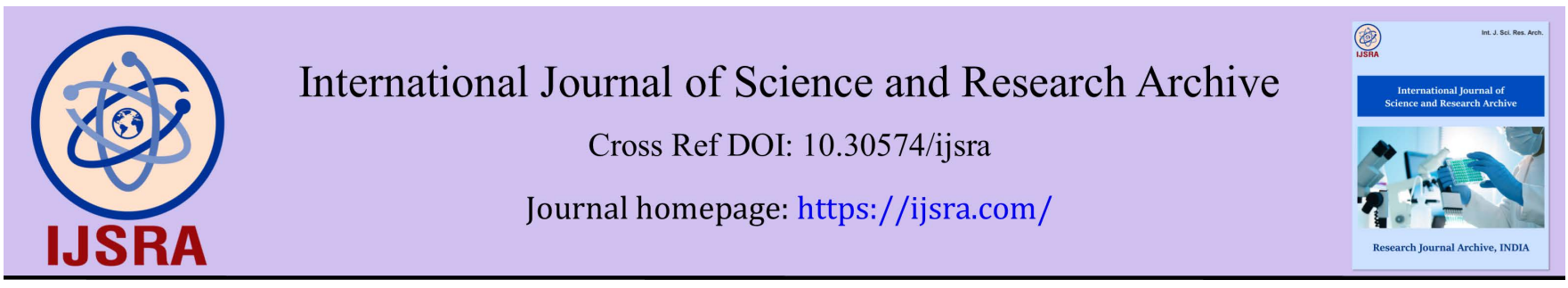

(REVIEW ARTICLE)

\title{
COVID-19 pandemic: What changes for orthodontists? A review of approaches to infection control
}

Tolulase Abosede Yemitan 1, 2, , Omolara Yeside Odunsi 1, Oyeyemi Oyebola Victor-Osho 1, Kikelomo Oluwabukola Adegbite 1, Babatunde Ogunbiyi Ogunbanjo 1, 2, Aderinsola Sophia Omotuyole ${ }^{2}$ and Oluranti Olatokunbo daCosta ${ }^{3}$

${ }^{1}$ Department of Child Dental Health, Lagos State University Teaching Hospital, Ikeja, Lagos, Nigeria.
${ }^{2}$ Department of Child Dental Health, Lagos State University College of Medicine, Ikeja, Lagos, Nigeria.
${ }^{3}$ Department of Child Dental Health, College of Medicine of the University of Lagos, Idi-araba, Lagos, Nigeria.

International Journal of Science and Research Archive, 2021, 02(01), 028-038

Publication history: Received on 08 January 2021; revised on 16 January 2021; accepted on 18 January 2021

Article DOI: https://doi.org/10.30574/ijsra.2021.2.1.0012

\begin{abstract}
This narrative review provides a comprehensive summary of the implications of severe acute respiratory syndrome coronavirus 2 (SARS-CoV-2) infection and coronavirus disease 2019 (COVID-19) on orthodontic treatment and a review of treatment protocols recommended for control of spread of this infection, using currently available data and literature. Relevant sources of information were searched using electronic databases including PubMed and Google Scholar and current reports from major health bodies such as Centers of Disease Control and Prevention, World Health Organization, Nigeria Centre for Disease Control, and major national orthodontic associations. The SARS-CoV-2 virus may be transmitted through direct or indirect contact with infected people through infected secretions such as saliva and respiratory secretions or through their respiratory droplets. Aerosol generating procedures often carried out in the orthodontic clinic can become a source of its spread as well as cross-infection. The asymptomatic patients and patients in their incubation period are also carriers of $S A R S-C o V-2$ and can be infectious. Elective orthodontic treatment should be delayed until there has been sufficient reduction in COVID-19 transmission rates from community transmission to cluster cases or according to official recommendations at national, sub-national or local level while urgent or emergency interventions that are vital for preserving a person's oral functioning, managing severe pain or securing quality of life should be provided. Treatment advice should be delivered remotely first when possible, and where necessary, in-person treatment can be performed in a well-prepared operatory following the necessary precautions and infection prevention and control (IPAC) protocol.
\end{abstract}

Keywords: Infection Control; Coronavirus Pandemic; Orthodontic practice; COVID-19

\section{Introduction}

The coronavirus disease, 2019 (COVID-19) since its emergence in December 2019 has spread rapidly and is now a global pandemic. The pathogen causing COVID-19 was named severe acute respiratory syndrome coronavirus 2 (SARS-CoV2). The World Health Organization on January 30, 2020 declared a public health emergency of international concern due to this disease [1]. In Nigeria, the first official case of COVID-19 was reported on February 27, 2020 [2]. As of 6th December 2020, a total of 68,937 confirmed cases of COVID-19 have been recorded by Nigeria Centre for Disease Control [3]. Additionally, as of 23rd July 2020, over 10.000 health care workers have been infected in Africa with over 1.4 million infected globally [4].

\footnotetext{
${ }^{*}$ Corresponding author: Dr Tolulase Yemitan

Department of Child Dental Health, Lagos State University Teaching Hospital, Ikeja, Lagos, Nigeria. 
This virus has the potential to cause severe acute respiratory tract infection among infected humans [5,6]. The average incubation period of COVID-19 ranges from 4 to 14 days [7]. Infected persons may present with upper respiratory tract infection with complaints of high-grade fever, a dry cough, and dyspnea [8]. Thus, various methods for reducing the spread of the virus have been advocated $[2,9]$.

Orthodontists and other dental care professionals are particularly at great risk because the oral cavity, is a portal of exit and entry of the virus, and therefore a major route of spread of the virus [10-13]. As a result of the pandemic, most authorities including World Health Organization, International and National Dental Associations recommended that routine non-essential oral health and aesthetic dental care be delayed until there has been sufficient reduction in COVID19 transmission rates from community transmission to cluster cases or according to official recommendations at national, sub-national or local level while urgent or emergency oral health care interventions should be provided [1420].

As orthodontists return to practice after weeks of shut down, exposure to asymptomatic carriers of $S A R S$-CoV-2 puts orthodontic practitioners under high risks of $S A R S-\mathrm{CoV}-2$ infection even as many orthodontists are currently under heavy workload to reschedule the accumulated patients whose treatments were significantly affected and postponed. It is therefore essential that all practitioners adapt their practices to new recommendations to protect themselves and patients until a vaccine is developed [21]. A study from Nigeria found that most Nigerian orthodontists and orthodontic residents responded that because of COVID-19, they would change their future practice of orthodontics, particularly with respect to placing a greater emphasis on infection control [22].

Because the outbreak of COVID-19 is recent and rapidly changing, there was little concrete scientific evidence to refer to, or protocols to follow. This review is therefore intended to analyze the implications for orthodontic practice, and the protocols various worldwide official health bodies, dental associations and orthodontic societies have recommended for orthodontists to follow.

\section{Material and methods}

To ensure that all relevant information regarding the rapidly evolving COVID-19 pandemic and orthodontic treatment implications were obtained, a wide selection of sources was searched and summarized. These sources included peerreviewed literature publications from electronic databases such as PubMed, Science Direct and Google Scholar using the following search terms: "Coronavirus," or "COVID-19," or "SARS-CoV-2," or "2019-nCoV," separately combined with "incubation," "transmission," "symptoms," "dentistry," "infection control," "orthodontic," and "protocol." Up-to-date reports and communications from major health bodies such as the Centers for Disease Control and Prevention (CDC), World Health Organization (WHO), Nigeria Centre for Disease Control, and major national orthodontic associations and health professional regulatory bodies were also referenced [Table 1]

Table 1 Sources of Literature and Information Included in This Review

\begin{tabular}{|c|c|c|c|c|}
\hline $\begin{array}{l}\text { Ref. } \\
\text { no. }\end{array}$ & Author & Country & Title/Topic & $\begin{array}{l}\text { Type of } \\
\text { study }\end{array}$ \\
\hline 1. & $\begin{array}{l}\text { World Health } \\
\text { Organization (2020) }\end{array}$ & Switzerland & $\begin{array}{l}\text { Statement on the second meeting of the International } \\
\text { Health Regulations (2005) Emergency Committee } \\
\text { regarding the outbreak of novel coronavirus (2019- } \\
n \mathrm{CoV})\end{array}$ & $\begin{array}{l}\text { Expert } \\
\text { opinion }\end{array}$ \\
\hline 2. & $\begin{array}{lr}\text { Nigeria } & \text { Centre for } \\
\text { Disease } & \text { Control } \\
(2020) & \\
\end{array}$ & Nigeria & $\begin{array}{l}\text { National interim guidelines for clinical management } \\
\text { of Covid-19 }\end{array}$ & $\begin{array}{l}\text { Expert } \\
\text { opinion }\end{array}$ \\
\hline 3. & $\begin{array}{lr}\text { Nigeria } & \text { Centre for } \\
\text { Disease } & \text { Control } \\
(2020) & \\
\end{array}$ & Nigeria & COVID-19 NIGERIA & $\begin{array}{l}\text { Expert } \\
\text { opinion }\end{array}$ \\
\hline 4. & $\begin{array}{l}\text { World Health } \\
\text { Organization (2020) }\end{array}$ & Africa & Healthcare workers in Africa infected with Covid-19 & $\begin{array}{l}\text { Expert } \\
\text { opinion }\end{array}$ \\
\hline 5. & $\begin{array}{l}\text { Khurshid Z, et al. } \\
(2020)\end{array}$ & $\begin{array}{l}\text { Saudi } \\
\text { Arabia }\end{array}$ & $\begin{array}{l}\text { Human Saliva: Non-Invasive Fluid for Detecting Novel } \\
\text { Coronavirus (2019- } n \mathrm{CoV})\end{array}$ & Review \\
\hline 6. & $\begin{array}{l}\text { World health } \\
\text { organization (2020) }\end{array}$ & Switzerland & $\begin{array}{l}\text { Transmission of } S A R S-C o V-2 \text { : implications for } \\
\text { infection prevention precautions: scientific brief, } 09 \\
\text { July } 2020\end{array}$ & $\begin{array}{l}\text { Scientific } \\
\text { brief }\end{array}$ \\
\hline
\end{tabular}




\begin{tabular}{|c|c|c|c|c|}
\hline 7. & $\begin{array}{llll}\text { Backer JA, et al. } \\
(2020)\end{array}$ & China & $\begin{array}{l}\text { Incubation period of } 2019 \text { novel coronavirus (2019- } \\
n \mathrm{CoV} \text { ) infections among travellers from Wuhan, China, } \\
20-28 \text { January } 2020\end{array}$ & $\begin{array}{l}\text { Investigatio } \\
\text { nal }\end{array}$ \\
\hline 8. & Guan W, et al. (2020) & China & $\begin{array}{l}\text { Clinical Characteristics of Coronavirus Disease } 2019 \\
\text { in China }\end{array}$ & Case series \\
\hline 9. & $\begin{array}{l}\text { World } \\
\text { organization (2020) }\end{array}$ & & Rolling updates on coronavirus disease (COVID19). & $\begin{array}{l}\text { Expert } \\
\text { opinion }\end{array}$ \\
\hline 10. & Sun $\mathrm{P}$, et al (2020) & China & $\begin{array}{l}\text { Prevention and Control of the Novel Coronavirus in } \\
\text { the Stomatological Hospital }\end{array}$ & $\begin{array}{l}\text { Investigatio } \\
\text { nal }\end{array}$ \\
\hline 11. & $\begin{array}{l}\text { Fakheran } 0 \text {, et al. } \\
(2020)\end{array}$ & Iran & $\begin{array}{l}\text { Saliva as a diagnostic specimen for detection of } S A R S- \\
\mathrm{CoV}-2 \text { in suspected patients: a scoping review }\end{array}$ & Review \\
\hline 12. & $\begin{array}{l}\text { Prospero E, et al. } \\
(2003)\end{array}$ & Italy & $\begin{array}{l}\text { Microbial aerosol contamination of dental healthcare } \\
\text { worker's faces and other surfaces in dental practice }\end{array}$ & $\begin{array}{l}\text { Investigatio } \\
\text { nal }\end{array}$ \\
\hline 13. & Rothe C, et al. (2020) & Germany & $\begin{array}{l}\text { Transmission of } 2019-n \mathrm{CoV} \text { infection from an } \\
\text { asymptomatic contact in Germany }\end{array}$ & Case series \\
\hline 14. & $\begin{array}{l}\text { FDI World Dental } \\
\text { Federation. }(2020)\end{array}$ & Switzerland & $\begin{array}{l}\text { FDI Statement. FDI responds to WHO's latest guidance } \\
\text { on the provision of oral health services in the context } \\
\text { of COVID-19 }\end{array}$ & $\begin{array}{l}\text { Expert } \\
\text { opinion }\end{array}$ \\
\hline 15. & $\begin{array}{l}\text { Nigerian } \quad \text { Dental } \\
\text { Association. (2020) }\end{array}$ & Nigeria & $\begin{array}{l}\text { NDA recommendations on Covid-19 protocol for } \\
\text { dental clinics }\end{array}$ & $\begin{array}{l}\text { Local } \\
\text { communicat } \\
\text { ions }\end{array}$ \\
\hline 16. & $\begin{array}{l}\text { The American Dental } \\
\text { Association. (2020) }\end{array}$ & $\begin{array}{l}\text { United } \\
\text { States }\end{array}$ & Coronavirus frequently asked questions & $\begin{array}{l}\text { Local } \\
\text { communicat } \\
\text { ions }\end{array}$ \\
\hline 17. & $\begin{array}{l}\text { World } \quad \text { health } \\
\text { organization (2020) }\end{array}$ & Switzerland & $\begin{array}{l}\text { Interim guidance. Considerations for the provision of } \\
\text { essential oral health services in the context of COVID- } \\
19\end{array}$ & $\begin{array}{l}\text { Expert } \\
\text { opinion }\end{array}$ \\
\hline 18. & $\begin{array}{l}\text { Centers for Disease } \\
\text { Control and } \\
\text { Prevention. }(2020)\end{array}$ & $\begin{array}{l}\text { United } \\
\text { States }\end{array}$ & $\begin{array}{l}\text { CDC recommendation: postpone non-urgent dental } \\
\text { procedures, surgeries, and visits }\end{array}$ & $\begin{array}{l}\text { Expert } \\
\text { opinion }\end{array}$ \\
\hline 19. & Jauhar P, et al. (2016) & $\begin{array}{l}\text { United } \\
\text { Kingdom }\end{array}$ & $\begin{array}{l}\text { Ingestion of an orthodontic archwire resulting in a } \\
\text { perforated bowel: a case report }\end{array}$ & Case series \\
\hline 20. & $\begin{array}{l}\text { Caprioglio A, et al. } \\
(2020)\end{array}$ & Italy & $\begin{array}{l}\text { Management of orthodontic emergencies during } \\
2019-n \mathrm{CoV}\end{array}$ & Review \\
\hline 21. & Lurie N, et al. (2020) & Norway & Developing Covid-19 vaccines at pandemic speed & $\begin{array}{l}\text { Expert } \\
\text { opinion }\end{array}$ \\
\hline 22. & $\begin{array}{llll}\text { Isiekwe } & \text { IG } & \text { et } & \text { al. } \\
(2020) & & & \end{array}$ & Nigeria & $\begin{array}{l}\text { Perceived impact of the COVID-19 pandemic on } \\
\text { orthodontic practice by orthodontists and } \\
\text { orthodontic residents in Nigeria }\end{array}$ & $\begin{array}{l}\text { Investigatio } \\
\text { nal }\end{array}$ \\
\hline 23. & Dong Y, et al. (2020) & China & $\begin{array}{l}\text { Epidemiological characteristics of } 2143 \text { pediatric } \\
\text { patients with } 2019 \text { coronavirus disease in China }\end{array}$ & Case series \\
\hline 24. & $\begin{array}{l}\text { Wu Z, McGoogan JM. } \\
(2020)\end{array}$ & China & $\begin{array}{l}\text { Characteristics of and important lessons from the } \\
\text { coronavirus disease } 2019 \text { (COVID-19) outbreak in } \\
\text { China: summary of a report of } 72,314 \text { cases from the } \\
\text { Chinese Center for Disease Control and Prevention. }\end{array}$ & Review \\
\hline 25. & Guan WJ, et al (2020) & China & Clinical Characteristics of Covid-19 in China & Case series \\
\hline 26. & Peng X, et al. (2020) & China & $\begin{array}{l}\text { Transmission routes of } 2019-n \mathrm{CoV} \text { and controls in } \\
\text { dental practice }\end{array}$ & Review \\
\hline 27. & Wei J, et al. (2016) & Hong Kong & $\begin{array}{l}\text { Airborne spread of infectious agents in the indoor } \\
\text { environment }\end{array}$ & Review \\
\hline 28. & Setti L, et al. (2020) & Italy & $\begin{array}{l}\text { Airborne transmission route of COVID-19: why } 2 \\
\text { meters } / 6 \text { feet of inter-personal distance could not be } \\
\text { enough }\end{array}$ & Review \\
\hline 29. & Gu J, et al. (2020) & China & $\begin{array}{l}\text { COVID-19: gastrointestinal manifestations and } \\
\text { potential fecal-oral transmission }\end{array}$ & Review \\
\hline
\end{tabular}




\begin{tabular}{|c|c|c|c|c|}
\hline 30. & Yang Y, et al (2020) & China & $\begin{array}{l}\text { Health services provision of } 48 \text { public tertiary dental } \\
\text { hospitals during the COVID-19 epidemic in China }\end{array}$ & $\begin{array}{l}\text { Investigatio } \\
\text { nal }\end{array}$ \\
\hline 31. & $\begin{array}{lr}\text { Nigeria } & \text { Centre for } \\
\text { Disease } & \text { Control } \\
(2020) & \\
\end{array}$ & Nigeria & $\begin{array}{l}\text { Infection prevention and control guideline for Covid- } \\
19\end{array}$ & $\begin{array}{l}\text { Expert } \\
\text { opinion }\end{array}$ \\
\hline 32. & $\begin{array}{l}\text { Abramovitz I, et al. } \\
(2020)\end{array}$ & $\begin{array}{l}\text { Israel, } \\
\text { United } \\
\text { States }\end{array}$ & $\begin{array}{l}\text { Dental care during the coronavirus disease } 2019 \\
\text { (COVID-19) outbreak: Operatory considerations and } \\
\text { clinical aspects }\end{array}$ & Review \\
\hline 33. & Lo Giudice R. (2020) & Italy & $\begin{array}{l}\text { The severe acute respiratory syndrome coronavirus-2 } \\
(S A R S C O V-2) \text { in dentistry. Management of biological } \\
\text { risk in dental practice }\end{array}$ & Review \\
\hline 34. & $\begin{array}{l}\text { World health } \\
\text { organization (2020) }\end{array}$ & Switzerland & $\begin{array}{l}\text { Rational use of personal protective equipment for } \\
\text { coronavirus disease (COVID-19) and considerations } \\
\text { during severe shortages }\end{array}$ & $\begin{array}{l}\text { Expert } \\
\text { opinion }\end{array}$ \\
\hline 35. & $\begin{array}{l}\text { Herron JB, et al. } \\
(2020)\end{array}$ & $\begin{array}{l}\text { United } \\
\text { Kingdom }\end{array}$ & $\begin{array}{l}\text { Personal protective equipment and Covid 19-a risk to } \\
\text { healthcare staff }\end{array}$ & Review \\
\hline 36. & $\begin{array}{l}\text { Centers for Disease } \\
\text { Control and } \\
\text { Prevention. (2020) }\end{array}$ & $\begin{array}{l}\text { United } \\
\text { States }\end{array}$ & Using Personal Protective Equipment (PPE) & $\begin{array}{l}\text { Expert } \\
\text { opinion }\end{array}$ \\
\hline 37. & Singh V, et al. (2020) & India & $\begin{array}{l}\text { The novel coronavirus and challenges for general and } \\
\text { paediatric dentists }\end{array}$ & Review \\
\hline 38. & $\begin{array}{l}\text { Parhizkar A, et al. } \\
(2020)\end{array}$ & Iran & $\begin{array}{l}\text { Dental considerations after the outbreak of } 2019 \\
\text { novel coronavirus disease: A review of literature }\end{array}$ & Review \\
\hline 39. & Kariwa H, et al (2004) & Japan & $\begin{array}{l}\text { Inactivation of SARS coronavirus by means of } \\
\text { povidone-iodine, physical conditions, and chemical } \\
\text { reagents }\end{array}$ & $\begin{array}{l}\text { Investigatio } \\
\text { nal }\end{array}$ \\
\hline 40. & Guo Y, et al. (2020) & China & $\begin{array}{l}\text { Control of } S A R S-C o V-2 \text { transmission in orthodontic } \\
\text { practice }\end{array}$ & Review \\
\hline 41. & $\begin{array}{l}\text { Vandenberghe B, et al. } \\
(2010)\end{array}$ & Belgium & $\begin{array}{l}\text { Modern dental imaging: a review of the current } \\
\text { technology and clinical applications in dental practice }\end{array}$ & Review \\
\hline 42. & Meng L, et al (2020) & China & $\begin{array}{l}\text { Coronavirus Disease } 2019 \text { (COVID-19): emerging and } \\
\text { future challenges for dental and oral medicine }\end{array}$ & Review \\
\hline 43. & $\begin{array}{l}\text { Hiraguchi H, et al. } \\
(2003)\end{array}$ & Japan & $\begin{array}{l}\text { Effect of rinsing alginate impressions using acidic } \\
\text { electrolyzed water on dimensional change and } \\
\text { deformation of stone models }\end{array}$ & $\begin{array}{l}\text { Investigatio } \\
\text { nal }\end{array}$ \\
\hline 44. & Kang YS, et al. (2017) & $\begin{array}{l}\text { United } \\
\text { States }\end{array}$ & $\begin{array}{l}\text { Effects of chlorine-based and quaternary ammonium- } \\
\text { based disinfectants on the wettability of a polyvinyl } \\
\text { siloxane impression material }\end{array}$ & $\begin{array}{l}\text { Investigatio } \\
\text { nal }\end{array}$ \\
\hline 45. & Cirillo N. (2020) & Australia & $\begin{array}{l}\text { COVID-19 outbreak: Succinct advice for dentists and } \\
\text { oral healthcare professionals }\end{array}$ & Review \\
\hline 46. & Guo J, et al. (2020) & China & $\begin{array}{l}\text { COVID-19: A novel coronavirus and a novel challenge } \\
\text { for oral healthcare }\end{array}$ & $\begin{array}{l}\text { Investigatio } \\
\text { nal }\end{array}$ \\
\hline 47. & Hurley S. (2020) & $\begin{array}{l}\text { United } \\
\text { Kingdom }\end{array}$ & Why re-invent the wheel if you've run out of road & $\begin{array}{l}\text { Expert } \\
\text { opinion }\end{array}$ \\
\hline 48. & Alharbi A, et al (2020) & $\begin{array}{l}\text { Saudi } \\
\text { Arabia }\end{array}$ & $\begin{array}{l}\text { Guidelines for dental care provision during the } \\
\text { COVID-19 pandemic }\end{array}$ & Review \\
\hline 49. & Hu T, et al. (2007) & China & $\begin{array}{l}\text { Risk of hepatitis } \mathrm{B} \text { virus transmission via dental } \\
\text { handpieces and evaluation of an anti-suction device } \\
\text { for prevention of transmission }\end{array}$ & $\begin{array}{l}\text { Investigatio } \\
\text { nal }\end{array}$ \\
\hline 50. & $\begin{array}{lll}\text { Fallahi HR, et al. } \\
(2020)\end{array}$ & Iran, Korea & $\begin{array}{l}\text { Being a front-line dentist during the covid-19 } \\
\text { pandemic: A literature review }\end{array}$ & Review \\
\hline 51. & $\begin{array}{l}\text { Spagnuolo G, et al. } \\
(2020)\end{array}$ & Italy & COVID-19 outbreak: An overview on dentistry & Review \\
\hline 52. & $\begin{array}{l}\text { Fu Shaw L, et al. } \\
(2018)\end{array}$ & Taiwan & $\begin{array}{l}\text { Factors influencing microbial colonies in the air of } \\
\text { operating rooms }\end{array}$ & $\begin{array}{l}\text { Investigatio } \\
\text { nal }\end{array}$ \\
\hline 53. & Dave M, et al. (2020) & $\begin{array}{l}\text { United } \\
\text { Kingdom }\end{array}$ & $\begin{array}{l}\text { Urgent dental care for patients during the COVID-19 } \\
\text { pandemic }\end{array}$ & $\begin{array}{l}\text { Expert } \\
\text { opinion }\end{array}$ \\
\hline
\end{tabular}




\section{Discussion}

\subsection{Clinical manifestations of COVID-19}

COVID-19 manifestations range from a complete lack of symptoms to symptomatic patients with severe complications leading to multiorgan dysfunction, septic shock, and systematic failure. COVID-19 can be classified into mild, moderate, severe, or critical diseases [23-25]. In a retrospective study of 72,000 cases, $81 \%$ of symptomatic patients presented with mild symptoms, whereas severe and critical symptoms were seen in $14 \%$ and $5 \%$ of the cases, respectively [24].

\subsection{Possible transmission routes of SARS-CoV-2 during orthodontic practice}

The orthodontic practice involves proximity of the patient's mouth and nose to the orthodontists and assisting staffs for long periods. These practitioners are therefore exposed to respiratory droplets when the patient talks, coughs or sneezes. They can also come in direct contact with saliva or blood of the infected patients during orthodontic procedures within the mouth such as photographing, impression taking, oral scanning, bracket and attachment bonding or removal, archwire changing, anchorage screw implantation. The risk of virus transmission is also increased with indirect contact with contaminated settings and environmental surfaces [26]. The use of orthodontic tools and materials that are not individually packaged or disposable such as pliers, power chains and adhesives, increases the risk of cross-infection. The use of high-speed handpieces and high-pressure 3-way syringes during bracket or attachment bonding and removal generates a large number of saliva or blood-mixed droplets and aerosols which could remain suspended in the air for long periods before they settle on environmental surfaces or enter the respiratory tract [27,28]. In addition, fecal-oral routes may also be a potential transmission route during orthodontic procedures, especially by patients' placement and removal of clear aligners, elastics, and other removable appliances [29].

\subsection{Pre-examination and triage of patients before orthodontic procedures}

To ensure that only patients requiring urgent or emergency receive treatment and that they have no symptoms suggestive of COVID-19 infection or previous risk exposure, screen patients before their appointments either by virtual/remote technology or telephone. Otherwise, triage should be done on arrival to the service or oral health care facility [30].

The Guideline for Infection Prevention and Control of COVID-19 by the Nigeria Centre for Disease Control [31], recommended a questionnaire screening of patients to take different actions according to the triage of the patients [Figure 1]. Secondly, the temperature of each patient should be taken using contact-free forehead thermometers [31]. If temperature is below 100.4 F, appointment may proceed [32]. If urgent or emergency orthodontic care is medically necessary for a patient who has, or is suspected of having, COVID-19, the patient should be referred to specialized oral health care services with appropriate measures in place to separate possible COVID-19 cases from other patients. Where appropriate, urgent or emergency oral health care interventions may also be provided on a home visit by a dedicated oral health care team applying strict infection prevention and control measures as locally prescribed [17].

\subsection{Personal protective measures}

\subsubsection{Hand hygiene}

To reinforce the compliance of hand washing, a 2-before and 3- after hand hygiene guideline was proposed. Specifically, the 2-before is to wash hands before the patient examination and before treatment procedures; the 3-after is to wash hands after touching the patient, after touching the surroundings and equipment without disinfection, and after touching the oral mucosa, blood, body fluid. Hand should be dried with disposable paper towels. In addition, orthodontic staff should avoid touching their own eyes, mouth, and nose [26]. Hand hygiene should also be applied before eating as well as before and after using the bathroom to avoid the fecal-oral transmission [29], artificial nails are not recommended [33].

\subsubsection{Personal protective equipment (PPE).}

Because droplets, contact, and aerosols are the major transmission routes of SARS-CoV-2 during orthodontic practice, barrier protection equipment is strongly recommended for all orthodontic staff. The protective measures include gloves; fluid resistant disposable gown, eye protection using face shield that covers the front and sides of the face or goggles and a medical mask. A fit tested N95 or FFP2 respirator (or higher) is recommended when aerosol generating procedures are performed [34]. 


\subsubsection{The order of wear of the personal protective equipment.}

A donning and doffing supervisor is recommended and if not possible, a buddy system should be installed to ensure providers are practicing proper infection control while donning and doffing PPE [35,36].

- Donning PPE: (1) Hand hygiene, (2) gown, (3) mask/respirator, (4) goggles and face shield, (5) hand hygiene, (6) gloves, (7) enter patient room.

- Doffing PPE: (1) Remove gloves, (2) remove gown, (3) exit patient room, (4) hand hygiene, (5) remove face shield and goggles, (6) Remove mask/respirator, (7) hand hygiene.

\subsection{Infection control during orthodontic procedures}

In the absence of a vaccine that can prevent infection [37], and as COVID-19 cases increase globally, orthodontic care providers should know the transmission routes of SARS-CoV-2, how to screen suspected patients, and what protective measures should be taken. Because there are no official post-pandemic guidelines for control of SARS-CoV-2 transmission for the orthodontic practice in Nigeria and worldwide as this manuscript was drafted, listed below are recommendations of the control measures that could be followed by orthodontic care providers based on previously published literature on control protocols in dental and orthodontic practice, and guidelines for the management of COVID-19 released by major health bodies, such as the Nigeria Centre for Disease Control, World Health Organization, and national dental associations[14-18,31].

\subsubsection{Appointment Scheduling}

During the epidemic period of the COVID-19, it is recommended to manage only orthodontic emergencies such as brackets debonding, archwire or ligature wire deformation or shifting, oral mucosa irritations, and anchorage implants loosening [20]. Nevertheless, orthodontists or assistants should evaluate the emergencies before allowing the patients to come to the office by requesting photographs or videos from the patients. If the emergency could be managed at home by remote instructions to the patients over the phone or other communication tools such as WhatsApp (Menlo Park, Calif), it is unnecessary for them to come to the office [20]. First-visit and nonemergency return-visit patients are suggested to schedule after the COVID-19 epidemic is effectively controlled in the area [14].

\subsubsection{Waiting room}

Patients should be unaccompanied unless they require assistance. Posters and flyers should be available around the waiting room to remind staff, patients and accompanying persons about hand hygiene protocol and sneezing and coughing etiquette [38].

\subsubsection{Pre-procedural Mouthrinses}

The recommendations to prevent the transmission of $S A R S-\mathrm{CoV}$-2 during orthodontic procedures include preprocedural mouthrinse with $1 \%$ hydrogen peroxide or $0.2 \%$ povidone iodine for 20 seconds prior to examination or starting any procedure for the purpose of reducing the salivary load of oral microbes, including SARS-CoV-2 [4,26,39]. The patients should be instructed to spit gently into a disposable cup. Use saliva ejectors with low or high volume to eject the gargle immediately to reduce the generation of droplets [40].

\subsubsection{Photographing}

For patients with high throat sensitivity, the reflector should not be placed too deep in the mouth, which may otherwise cause irritation, nausea, and vomiting, leading to the generation of droplets [41]. Photographers should strictly implement the principle of "one patient, one use, and one disinfection" for auxiliary equipment such as retractors and reflectors [40].

\subsubsection{X-ray examination.}

The intraoral $\mathrm{x}$-ray examination, most used radiographic technique in dental practice can stimulate saliva secretion, gagging, and coughing [41], which increases the risk of infection transmission. Therefore, extraoral radiographs, such as panoramic radiography and cone-beam computed tomography, are more appropriate alternatives during the epidemic period of COVID-19 [42].

\subsubsection{Dental impression taking.}

Before taking the dental impression, patients should be informed of the potential risks of nausea and gagging in advance. Patients should also be instructed to inhale through the nose and exhale out the mouth. After solidification and taking 
out of the impression, wash the saliva or blood on the surface gently with slow running water to prevent splashing and then disinfect the impressions [40]. Alginate and silicone rubber impressions should be disinfected by immersing in $1000 \mathrm{mg} / \mathrm{L}$ chlorine-containing disinfectants for 15-30 minutes before they are cast or sent to the factories [43,44].

\subsubsection{Digital oral scanning.}

Patients who need clear aligner orthodontic treatment and other customized appliances can obtain digital dental models through oral scanning. During the scanning, the staff should avoid inducing the pharyngeal reflex of the patient by gentle operation when scanning the molar regions. To avoid aerosol in the air caused by using a 3-way syringe to dry the tooth surfaces during the scanning, cotton rolls could be alternatively used to wipe the patient's tooth surfaces while keep the mouth dry by using saliva ejectors. Use the touchpad of the scanning bar to control and avoid the use of the touch screen, which may not be effectively disinfected because of its special screen characteristics. After scanning, the handle of the scanner should be sprayed and wiped with $75 \%$ alcohol. The intraoral head of the scanner should be disinfected after each use [26].

\subsubsection{Treatment plan-making.}

Attempt to resolve issues remotely before submitting to an in-person emergency appointment. Ensure patients have contact information necessary for virtual or photographic updates [45] and make use of video consultation [46,47]. Mobile-based notification systems such as WhatsApp and WeChat have been shown to be the most popular messenger apps and the most usable by inexperienced audiences [20]. For the first-visit patients, after the initial examinations and records have been taken, it is recommended to make the next appointment for return-visit on a separate day to communicate with the patients about treatment alternatives [41].

\subsubsection{Bracket or attachment bonding and removal.}

Aerosol generating procedures should be avoided or minimized, and minimally invasive procedures using hand instruments should be prioritized [48]. When aerosol generating procedures cannot be avoided, ensure assistance during procedures (four-handed dentistry), the use of high-speed suction and of a rubber dam, when possible, as well as the use of appropriate PPE - including a fit tested N95 or FFP2 respirator, or higher [17]. If high-speed handpieces are necessary to use, an anti-retraction handpiece with specially designed anti-retractive valves or other anti-reflux designs is recommended [49]. Therefore, in addition to the use of appropriate PPE, the use of high-volume saliva ejectors should be adopted to prevent cross-infection as well as to improve working efficiency. A plasma air sterilizer should be turned on continuously for air disinfection, especially during the procedures related to the use of high-speed handpieces and high-pressure 3-way syringes, and the windows of the room should be open to allow natural ventilation $[50,51]$.

\subsubsection{Archwire changing and bending.}

Individually packaged archwires are recommended to use in fixed orthodontic treatment to avoid cross-infection. When the archwires need to be adjusted during the orthodontic treatment, such as bending or the adding of the curve, spray and wipe the archwire with $75 \%$ alcohol after it is removed from the mouth. While bending, two layers of gloves are suggested to be worn in case of glove tear or potential skin laceration from the archwires [40].

\subsubsection{Removable appliance adjustment.}

Removable appliances, including clear aligners, are directly in contact with the saliva and the oral mucosa, making them potential transmission media of SARS-CoV-2. Appliances should be washed and sprayed with $75 \%$ alcohol or $1000 \mathrm{mg} / \mathrm{L}$ chlorine-containing disinfectants before the adjustment. Care should be taken to avoid pharyngeal reflex during wear and removal [40].

\subsubsection{Disinfection of the dental settings between the treatment of patients.}

The disinfection of dental settings and related surfaces should be done after each patient. Flush saliva ejector tubes with at least $150 \mathrm{ml}$ of $1000 \mathrm{mg} / \mathrm{L}$ chlorine-containing disinfectant. Flush the spittoon area and clean with $1000 \mathrm{mg} / \mathrm{L}$ chlorine-containing disinfectant. Run the handpieces and 3-way syringes to discharge water for 30 seconds, which will help to flush out the patient materials that may have entered the waterlines. The dental chair should be sprayed with 75\% alcohol and completely wiped and disinfected with $1000 \mathrm{mg} / \mathrm{L}$ chlorine-containing disinfectant.

After disinfection, cover with disposable films all the surfaces that are touched during procedures and change these protections between each patient [40]. 


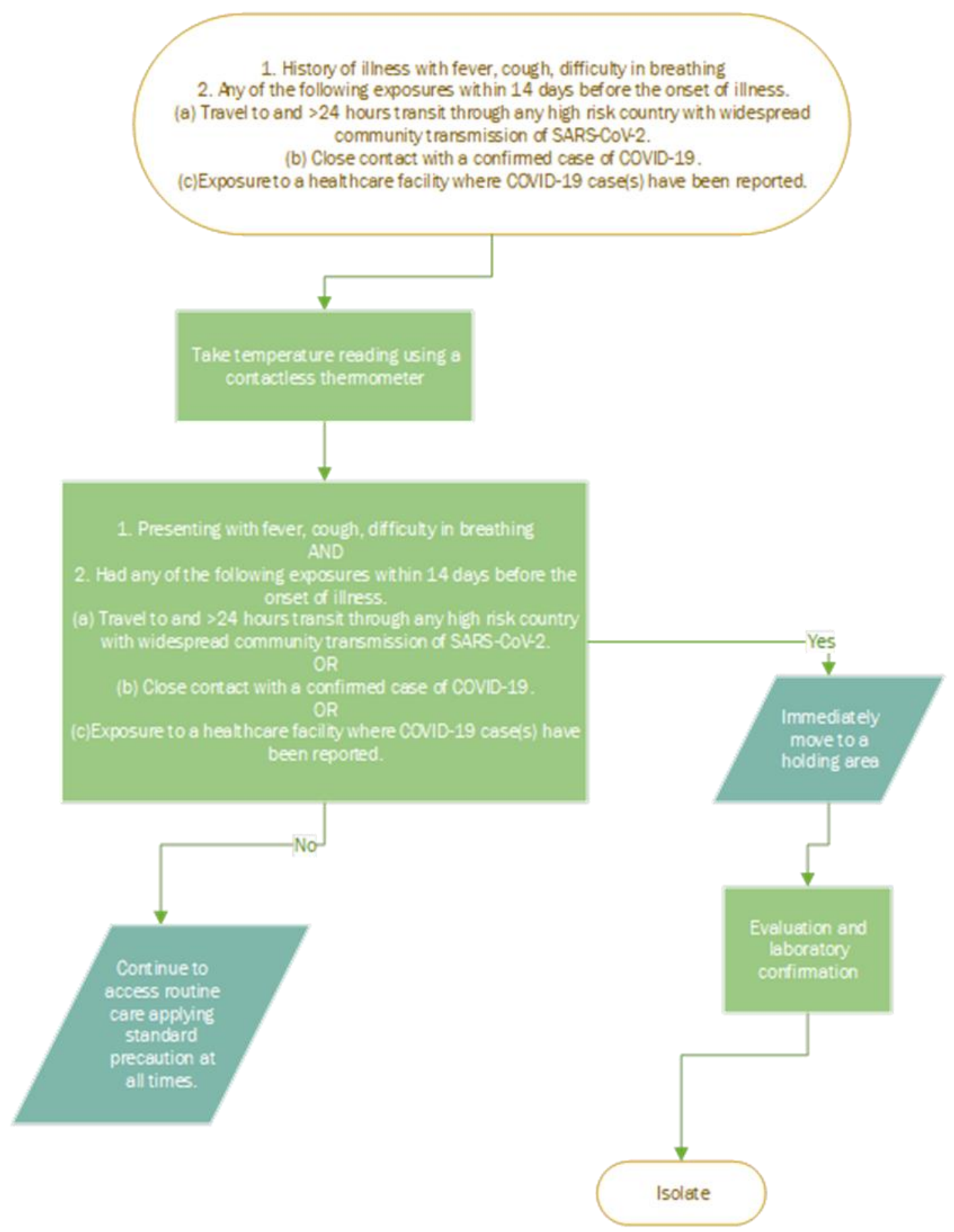

Figure 1 The procedures of pre-examination and triage before the orthodontic practice

\subsubsection{Instructions to the patient.}

Many aspects of orthodontic treatment require the cooperation of patients, such as wearing and removal of clear aligners, retainers, functional appliances and rubber band elastics. Ensure proper hand hygiene before and after these activities. In addition, patients who wear removable appliances should be instructed to keep the appliances stored in containers after removal rather than out on open surfaces to prevent the possible transmission of $S A R S$-CoV-2 [40].

\subsubsection{Management for reusable items and medical wastes.}

All patient-care items must be sterilized or otherwise subjected to high-level disinfection according to Spaulding's criteria or the manufacturer's instructions for times and temperatures recommended. Re-usable eye protection and face shields must be cleaned and disinfected prior to re-use. There is no standard or evidence-based methods for 
reprocessing masks or respirators. Reprocessing should be only considered when there is a critical PPE shortage [34]. The medical waste generated should be stored in specially made medical waste bags then transported and disposed of in accordance with the management requirements for medical waste [40].

\subsubsection{Air and environment disinfection.}

Avoid the use of split air conditioning or other types of recirculation devices and consider installation of filtration systems. It is recommended to ventilate the rooms in-between patients. Natural ventilation is a simple and effective way of air purification [52]. If it is not possible to allow the exchange of natural air (at least 20-30 min), forced ventilation systems with High Efficiency Particulate Air (HEPA) filters must be used, paying attention to the periodic replacement of the filters $[40,52]$. Plasma air sterilizers can be left continuously running for air disinfection in an environment with human activity, especially in the working area and the waiting area. Ultraviolet germicidal irradiation of $254 \mathrm{~nm}$ can be used for environmental surface disinfection for 30-60 minutes, twice a day. If the ultraviolet light is not available, spray and wipe the surfaces, such as the floor, desk, and chair, with $1000 \mathrm{mg} / \mathrm{L}$ chlorine-containing disinfectant every 2-3 hours [40].

\subsubsection{Patient follow-up}

Digital follow up of patients through photographs or video calls using the phone or other communication tools is recommended not only to monitor the orthodontic progress but also to minimize the repeated patient contact and ensure patient safety in case of orthodontic emergencies. [20,53]

\section{Conclusion}

Orthodontics is a profession that works directly with the oral cavity and is therefore very exposed to this virus or other infectious agents. Because there may still be asymptomatic patients or patients in the incubation period after the resumption of regular clinical activities, and many orthodontic patients in need of orthodontic return-visits, all procedures related to the orthodontic practice should be strictly performed with preventive measures to control the potential transmission of $S A R S-\mathrm{CoV}-2$.

As more studies are conducted on SARS-CoV-2 to show which interventions significantly protect against transmission, a more concrete guide will emerge to allow the safest oral healthcare protocols to be implemented. As orthodontic practices begin to reopen, consequences for patients, students, faculty, and orthodontists will be unveiled revealing economic impacts and impact on orthodontic education.

\section{Compliance with ethical standards}

\section{Acknowledgments}

The authors hereby appreciate and thank all contributors.

\section{Disclosure of conflict of interest}

All authors hereby declare that there is no relationship with any party that may present a potential conflict of interest.

\section{References}

[1] World Health Organization. Statement on the second meeting of the International Health Regulations. Emergency Committee regarding the outbreak of novel coronavirus (2019-nCoV). 2005.

[2] Nigeria Centre for Disease Control (NCDC). National interim guidelines for clinical management of Covid-19.

[3] Nigeria Centre for Disease Control (NCDC). COVID-19 NIGERIA.

[4] World Health Organization Regional office for Africa. 23 July 2020.

[5] Khurshid Z, Asiri FYI, Wadaani HA. Human Saliva: Non-Invasive Fluid for Detecting Novel Coronavirus (2019nCoV). Int J Environ Res Public Health. 2020 Apr;17(7):22-5.

[6] World Health Organization. Transmission of SARS-CoV-2: implications for infection prevention precautions: scientific brief. 09 July 2020. 
[7] Backer JA, Klinkenberg D, Wallinga J. Incubation period of 2019 novel coronavirus (2019-nCoV) infections among travellers from Wuhan, China, 20-28 January 2020. Euro Surveill. 2020 Feb;25(5):2000062.

[8] Guan W, Ni Z, Hu Y, Liang W, Ou C, He J, et al. Clinical Characteristics of Coronavirus Disease 2019 in China. N Engl J Med. 2020 Feb;382(18):1708-20.

[9] World Health Organization. Rolling updates on coronavirus disease (COVID19).

[10] Sun P, Zhao L, Yu M, Zhang M. Prevention and Control of the Novel Coronavirus in the Stomatological Hospital. Eur J Prev Med. 2020 Mar;8(2):12-5.

[11] Fakheran 0, Dehghannejad M, Khademi A. Saliva as a diagnostic specimen for detection of SARS-CoV-2 in suspected patients: a scoping review. Infect Dis Poverty. 2020 July;9(1):100.

[12] Prospero E, Savini S, Annino I. Microbial aerosol contamination of dental healthcare worker's faces and other surfaces in dental practice. Infect Control Hosp Epidemiol. 2003 Feb;24(2):139-41.

[13] Rothe C, Schunk M, Sothmann P, Bretzel G, Froeschl G, Wallrauch C, et al. Transmission of 2019-nCoV infection from an asymptomatic contact in Germany. N Engl J Med. 2020 Mar;382(10):970-1.

[14] FDI World Dental Federation. FDI Statement. FDI responds to WHO's latest guidance on the provision of oral health services in the context of COVID-19.14 August 2020.

[15] Nigerian Dental Association. NDA recommendations on Covid-19 protocol for dental clinics.

[16] The American Dental Association. Coronavirus frequently asked questions URL. 27 Mar 2020.

[17] World Health Organization. Interim guidance. Considerations for the provision of essential oral health services in the context of COVID-19. 3 August 2020.

[18] Centers for Disease Control and Prevention. CDC recommendation: postpone non-urgent dental procedures, surgeries, and visits URL. 27 Mar 2020.

[19] Jauhar P, Machesney MR, Sharma PK. Ingestion of an orthodontic archwire resulting in a perforated bowel: a case report. J Orthod. 2016 Sept;43(3):237-40.

[20] Caprioglio A, Pizzetti GB, Zecca PA, Fastuca R, Maino G, Nanda R. Management of orthodontic emergencies during 2019-NCOV. Prog Orthod. 2020;21:10.

[21] Lurie N, Saville M, Hatchett R, Halton J. Developing Covid-19 vaccines at pandemic speed. N Engl J Med. 2020 May; 382(21):1969-73.

[22] Isiekwe IG, Adeyemi TE, Aikins EA, Umeh OD. Perceived impact of the COVID-19 pandemic on orthodontic practice by orthodontists and orthodontic residents in Nigeria, J World Fed Orthod. 2020 Sept;9(3):123-8.

[23] Dong Y, Mo X, Hu Y, Qi X, Jiang F, Jiang Z, et al. Epidemiological characteristics of 2143 pediatric patients with 2019 coronavirus disease in China. J Emerg Med. 2020 Apr;58(4):712-3.

[24] Wu Z, McGoogan JM. Characteristics of and important lessons from the coronavirus disease 2019 (COVID-19) outbreak in China: summary of a report of 72,314 cases from the Chinese Center for Disease Control and Prevention. JAMA. 2020 Apr;323(13):1239-42.

[25] Guan WJ, Zhong NS. Clinical Characteristics of Covid-19 in China. Reply. N Engl J Med. 2020 Mar;382(19):1861-2.

[26] Peng X, Xu X, Li Y, Cheng L, Zhou X, Ren B. Transmission routes of 2019-nCoV and controls in dental practice. Int J Oral Sci. 2020 Mar;12(1):9.

[27] Wei J, Li Y. Airborne spread of infectious agents in the indoor environment. Am J Infect Control. 2016 Sept;44(9):S102-8.

[28] Setti L, Passarini F, De Gennaro G, Barbieri P, Perrone MG, Borelli M, et al. Airborne transmission route of COVID19: why 2 meters/6 feet of inter-personal distance could not be enough. Int J Environ Res Public Health. 2020 Apr;17(8):2932.

[29] Gu J, Han B, Wang J. COVID-19: gastrointestinal manifestations and potential fecal-oral transmission. Gastroenterology. 2020 May;158(6):1518-9.

[30] Yang Y, Zhou Y, Liu X, Tan J. Health services provision of 48 public tertiary dental hospitals during the COVID-19 epidemic in China. Clin Oral Investig. 2020 May;24(5):1861-4. 
[31] Nigeria Centre for Disease Control (NCDC). Infection prevention and control guideline for Covid-19. 13 August 2020.

[32] Abramovitz I, Palmon A, Levy D, Karabucak B, Kot-Limon N, Shay B, et al. Dental care during the coronavirus disease 2019 (COVID-19) outbreak: Operatory considerations and clinical aspects. Quintessence Int. 2020; 51: 418-29.

[33] Lo Giudice R. The severe acute respiratory syndrome coronavirus-2 (SARS- CoV-2) in dentistry. Management of biological risk in dental practice. Int J Environ Res Public Health. 2020; 17: 3067.

[34] World Health Organization. Interim guidance. Rational use of personal protective equipment for coronavirus disease (COVID-19) and considerations during severe shortages.

[35] Herron JB, Hay-David AG, Gilliam AD, Brennan PA. Personal protective equipment and Covid 19-a risk to healthcare staff? Br J Oral Maxillofac Surg. 2020; 58: 500-2.

[36] Centers for Disease Control and Prevention. Using Personal Protective Equipment (PPE). 14 July 2020.

[37] Singh V, Lehl GK, Talwar M, Luthra A. The novel coronavirus and challenges for general and paediatric dentists. Occup Med. 2020; 70: 320-2.

[38] Shamszadeh S, Parhizkar A, Mardani M, Asgary S. Dental considerations after the outbreak of 2019 novel coronavirus disease: A review of literature. Arch Clin Infect Dis. 15(2):e103257. doi: 10.5812/archcid.103257.

[39] Kariwa H, Fujii N, Takashima I. Inactivation of SARS coronavirus by means of povidone-iodine, physical conditions, and chemical reagents. Jpn J Vet Res. 2004; 52: 105-12.

[40] Guo Y, Jing Y, Wang Y, To A, Du S, Wang L, et al. Control of SARS-CoV-2 transmission in orthodontic practice. Am J Orthod Dentofacial Orthop. 2020;158:321-329.

[41] Vandenberghe B, Jacobs R, Bosmans H. Modern dental imaging: a review of the current technology and clinical applications in dental practice. Eur Radiol. 2010; 20: 2637-55.

[42] Meng L, Hua F, Bian Z. Coronavirus Disease 2019 (COVID-19): emerging and future challenges for dental and oral medicine. J Dent Res. 2020; 99: 481-7.

[43] Hiraguchi $\mathrm{H}$, Nakagawa $\mathrm{H}$, Uchida $\mathrm{H}$, Tanabe N. Effect of rinsing alginate impressions using acidic electrolyzed water on dimensional change and deformation of stone models. Dent Mater J. 2003; 22: 494-506.

[44] Kang YS, Rueggeberg F, Ramos V Jr. Effects of chlorine-based and quaternary ammonium-based disinfectants on the wettability of a polyvinyl siloxane impression material. J Prosthet Dent. 2017; 117: 266-70.

[45] Cirillo N. COVID-19 outbreak: Succinct advice for dentists and oral healthcare professionals. Clin Oral Investig. 2020;19:1-7.

[46] Guo J, Xie H, Liang M, Wu H. COVID-19: A novel coronavirus and a novel challenge for oral healthcare. Clin Oral Investig. 2020; 24: 2137-8.

[47] Hurley S. Why re-invent the wheel if you've run out of road? Br Dent J. 2020; 228: 755-6.

[48] Alharbi A, Alharbi S, Alqaidi S. Guidelines for dental care provision during the COVID-19 pandemic. Saudi Dent J. 2020; 32: 181-6.

[49] Hu T, Li G, Zuo Y, Zhou X. Risk of hepatitis B virus transmission via dental handpieces and evaluation of an antisuction device for prevention of transmission. Infect Control Hosp Epidemiol. 2007; 28: 80-2.

[50] Fallahi HR, Keyhan SO, Zandian D, Kim SG, Cheshmi B. Being a front-line dentist during the covid-19 pandemic: A literature review. Maxillofac Plast Reconstr Surg. 2020; 42: 12.

[51] Spagnuolo G, De Vito D, Rengo S, Tatullo M. COVID-19 outbreak: An overview on dentistry. Int J Environ Res Public Health. 2020; 17: 2094.

[52] Fu Shaw L, Chen IH, Chen CS, Wu HH, Lai LS, Chen YY, et al. Factors influencing microbial colonies in the air of operating rooms. BMC Infect Dis. 2018; 18: 4.

[53] Dave M, Seoudi N, Coulthard P. Urgent dental care for patients during the COVID-19 pandemic. Lancet. 2020; 395: 1257. 